\title{
NEGATIVE IONS OF ATOMS AND DIATOMIC AND TRIATOMIC MOLECULES
}

\author{
Leonid I. Grethcikhin ${ }^{a}$, Viktoriya M. Komarovskaya ${ }^{\mathrm{b}}$ \\ ${ }^{a}$ Belarusian State Academy of Communications, Minsk, Belarus, \\ e-mail: Gretchihin@yandex.ru, \\ ORCID iD: (i) http://orcid.org/0000-0002-5385-9037 \\ ${ }^{b}$ Belarusian National Technical University, Minsk, Belarus, \\ e- mail: maratovna81@tut.by
}

DOI: 10.5937/vojtehg64-9685

FIELD: Materials, Nanotechnology, Structure and properties of negative ions ARTICLE TYPE: Original Scientific Paper ARTICLE LANGUAGE: English

\section{Summary:}

Electron affinity is not determined by solving the Schrödinger equation, but by using a wide range of various types of interactions. In atoms, the bound between the external electron and the integrated electric dipole moment of a neutral atom mainly contributes to electron affinity. In diatomic molecules, electron affinity is defined mainly by the interaction of the external electron and the integrated electric dipole moment of the nearest ion. In a triatomic molecule, the external electron interacts with all integrated dipole moments of the positive core.

Key words: dipole moment, negative ion, atom, diatomic molecule, triatomic molecule.

\section{Introduction}

At the present moment, due to the application of ion-plasma sputtering of nano-sized strengthening layers using vacuum high-current voltage arcs, there is a need for clarifying the role of negative ions in the process of field-emission cathodes spattering. To manage these arcs, one should know how negative ions are formed and how their existence influences the plasma state of the voltage arc.

A serious consideration was paid to negative ions in the middle of the 1950s for the first time, as a result of the beginning of outer space development projects, when direct measurements helped to establish the fact that there were only negative ions near the rocket vehicle surface in 
the area of the Earth's shadow at flight altitudes of $90-130 \mathrm{~km}$ (Johnson, 1956). It led to detailed studies of negative ions formation and the identification of physical and chemical processes occurring when negative ions exist under different conditions (Massey, 1976) and (Grethcikhin, 2003). Experimental works have been dedicated mainly to measuring affinity energies and to chemical reactions behavior with formation and decomposition of negative ions (Massey, 1976).

Theoretical studies have been oriented towards the development of the calculation methods for the energies of electron affinity to atoms and molecules using Hartree-Fock wave functions and self-consistent potential by solving the Schrödinger equation in consideration of the correlation interaction between valence electrons (Massey, 1976). The conducted theoretical studies of negative ions formation gave no positive results as the applied model of the centrally symmetric field did not comply with actual interactions occurring in negative ions.

Formations of negative ions and chemical reactions behavior with participation of negative ions were studied mainly on glow discharges, i.e. an attempt was made to simulate in some way conditions of the upper atmosphere layers in laboratory conditions. These studies have shown a significant role negative ions play in many cases (Massey, 1976).

Theoretical and experimental studies of the negative ions influence in the process of artificial Earth satellites flights were performed in 196070s (Grethcikhin, 2003). As a result, a strong frontal luminescence of artificial satellites, especially in the area of the Earth's shadow (Grethcikhin effect), was predicted and direct measurements were taken on board of the long-term space station "Salyut-4" at a flight altitude of $350 \mathrm{~km}$ (Grethcikhin, 2003). These measurements proved the theoretical prediction concerning the brightness of luminescence and the distribution of luminescence intensiveness around a flight vehicle.

The role of negative ions in voltage arcs and electrical sparks under atmospheric pressure and upon the effect of strong laser irradiation with a formation of a double electric layer was studied by Professor L.I. Grethcikhin and his co-workers (Grethcikhin, Tyunina, 1967), (Grethcikhin, Minko, 1967) and (Grethcikhin, 2008). These works show that the temperature of flares flowing out of cathode spots is determined by the process of the negative ions ionization and that occurring electrical currents of the double electrical layer compensation form the voltage arc plasma without electrical current flow.

At the present time, due to strengthening of construction materials and a reduction of friction forces with a use of nanotechnologies, a need for a detailed investigation of the plasma state formation arises again; this time, the studies are to be conducted in the vacuum high-current voltage arcs when negative ions are formed. The objective has been set 
out: to conduct a detailed investigation of the negative ions formation process mainly in cathode flares taking into consideration the latest achievements in the field of nanotechnologies. To achieve this objective, it is necessary to solve the following issues:

- to consider the formation of negative ions in the process of electrons and atoms interaction taking into account the occurrence of integrated electric dipole moments in atoms and polarization of these moments;

- to clarify what interactions do determine the energies of electron affinity in diatomic molecules in consideration of the occurrence of integrated electric moments in the ions of the positive molecule core;

- to clarify what interactions do determine the energies of electron affinity in triatomic molecules in consideration of the occurrence of integrated electric moments in the ions of the positive core.

Let us consider the set tasks consistently.

\section{Formation of Negative lons in Complex Atomic Systems}

It has been established so far in the works (Grethcikhin, 2003), (Grethcikhin, Shmermbekk, 2010) that, in complex atomic systems, a deformation of the spherically symmetric s-states occurs as a result of the $p$-s, $d$-s or $f$-s interactions of the electron shells. It leads to the creation of the integrated electric dipole moment relating to the complex atom center. Table 1 shows the performed calculations of the integrated electric moment for atoms and positive ions of carbon, oxygen, titanium and copper, taking into consideration Hund's rule.

Table 1 - Integrated electric moments for atoms and positive ions of carbon, oxygen, titanium and copper

Таблица 1 -Встроенные электрические моменты для атомов углерода, кислорода и титана

Tabela 1 - Ugrađeni električni momenti atoma ugljenika, kiseonika i titana

\begin{tabular}{|c|c|c|c|c|c|}
\hline Element & \multicolumn{5}{|c|}{ Electric dipole moment, Cm x 10 } \\
\hline Carbon [8] & $2 \mathrm{p}^{1}-$ & $2 \mathrm{p}^{1}-$ & $2 \mathrm{p}^{2}-$ & $2 \mathrm{p}^{2}-2 \mathrm{~s}^{2}$ & $p_{\mathrm{e}, \mathrm{C}}=3.935 /$ \\
$r_{a}=0.904 \AA$ & $2 \mathrm{~s}^{1}$ & $2 \mathrm{~s}^{2}$ & $2 \mathrm{~s}^{1}$ & -4.490 & 3.089 \\
& 5.830 & -3.811 & 6.466 & & $p_{\mathrm{e}, \mathrm{C}}^{+}=$ \\
& & & & & 1.976 \\
\hline Oxygen & $2 \mathrm{p}^{1}-$ & $2 \mathrm{p}^{1}-$ & $2 \mathrm{p}^{2}-$ & $2 \mathrm{p}^{2}-$ & $p_{\mathrm{e}, \mathrm{O}}=2.891$ \\
$r_{a}=0.672 \AA$ & $2 \mathrm{~s}^{1}$ & $2 \mathrm{~s}^{2}$ & $2 \mathrm{~s}^{1}$ & $2 \mathrm{~s}^{2}$ & 2.705 \\
{$[8]$} & 9.375 & -7.252 & 18.775 & -17.985 & $p_{\mathrm{e}, \mathrm{O}^{+}}=2.755$ \\
& $2 \mathrm{p}^{3}-$ & $2 \mathrm{p}^{3}-$ & $2 \mathrm{p}^{4}-$ & $2 \mathrm{p}^{4}-$ & \\
& $2 \mathrm{~s}^{1}$ & $2 \mathrm{~s}^{2}$ & $2 \mathrm{~s}^{1}$ & $2 \mathrm{~s}^{2}$ & \\
& 8.684 & -7.715 & -8.491 & 7.495 & \\
\hline
\end{tabular}




\begin{tabular}{|c|c|c|c|c|c|c|}
\hline $\begin{array}{c}\text { Titanium } \\
r_{a}=1.992 \AA \\
{[9]}\end{array}$ & $\begin{array}{c}3 d^{1}- \\
4 s^{1} \\
5.506\end{array}$ & $\begin{array}{c}3 d^{1}- \\
4 s^{2} \\
-3.446\end{array}$ & $\begin{array}{c}3 d^{2}- \\
4 s^{1} \\
5.544\end{array}$ & $\begin{array}{c}3 d^{2}- \\
4 s^{2} \\
-3.524\end{array}$ & $\begin{array}{c}p_{\mathrm{e}, \mathrm{Ti}}=4.080 \\
4.705 \\
p_{\mathrm{e}, \mathrm{Ti}}^{+}=2.020 \\
\mathrm{p}_{\mathrm{e}, \mathrm{Ti}}^{+}= \\
10.946\end{array}$ & \\
\hline $\begin{array}{c}\text { Copper } \\
r_{a}=1.762\end{array}$ & $\begin{array}{c}3 d_{1}- \\
4 s \\
20.48 \\
5 \\
3 d_{6}- \\
4 s \\
-7.981\end{array}$ & $\begin{array}{c}3 \mathrm{~d}_{2}- \\
4 \mathrm{~s} \\
- \\
18.034 \\
3 \mathrm{~d}_{7}- \\
4 \mathrm{~s} \\
6.784\end{array}$ & $\begin{array}{c}3 d_{3}- \\
4 s \\
14.926 \\
3 d_{8}-4 s \\
-5.695\end{array}$ & $\begin{array}{c}3 \mathrm{~d}_{4}-4 \mathrm{~s} \\
-12.225 \\
3 \mathrm{~d}_{9}- \\
4 \mathrm{~s} \\
4.864\end{array}$ & $\begin{array}{c}3 d_{5}-4 s \\
9.904 \\
3 d_{10}-4 s \\
-4.196\end{array}$ & $\begin{array}{c}\mathrm{p}_{\mathrm{e}, \text { result }} \\
\mathrm{Cu} \\
8.831 \\
10.132 \\
\mathrm{p}_{\mathrm{e}, \text { result }} \\
\mathrm{Cu^{+ }} \\
0 ; \\
9,39 ; 4,6 \\
0\end{array}$ \\
\hline
\end{tabular}

According to Hund's rule, the arrangement of electron spins for carbon, oxygen, and titanium is shown in Fig. 1 and for copper in Fig. 2.

For carbon and oxygen, the interaction of $2 p$-electrons with the $2 s^{1}$ electron is taken with the sign "+" and with the $2 s^{2}$ electron - with the sign "-" (Grethcikhin, 2008) and (Grethcikhin, Shmermbekk, 2010). In oxygen, the first deepest cell of the $p$-orbit contains two electrons with opposite spins. It leads to the instance when the second electron in the third cell has the opposite-by-sign interaction of the $2 p^{1}$-electrone in the first cell with the electrons in the $2 s$-state. The second, the third and the fourth electrons after releasing of the first cell take positions in accordance with Hund's rule, i.e. with the maximum values of the resultant spin. As for titanium, ionization leads to electron loss in the $4 \mathrm{~s}$ or in $3 d$ core. Both cases are shown in Fig. 1.

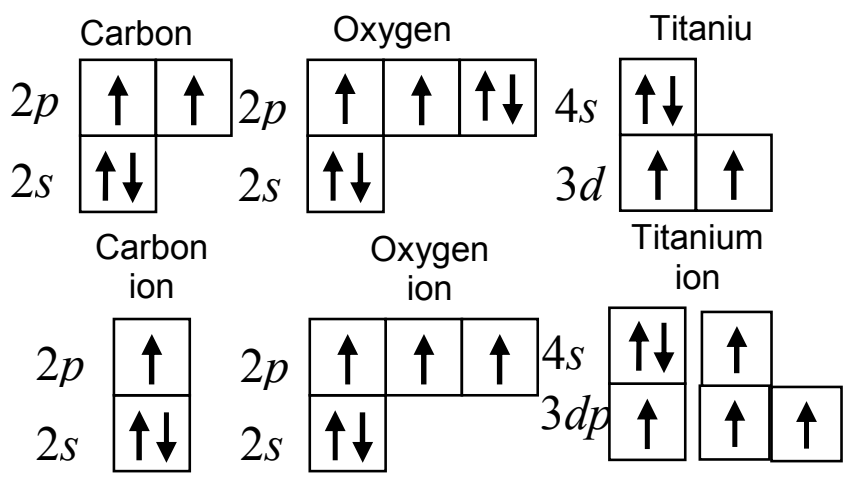

Figure 1 - Arrangement of spins of electrons in accordance with Hund's rule Фигура 1 - Расположение спинов электронов в соответствии с правилом Хунда Slika 1 - Raspored spina elektrona, u skladu sa pravilom Hunda 


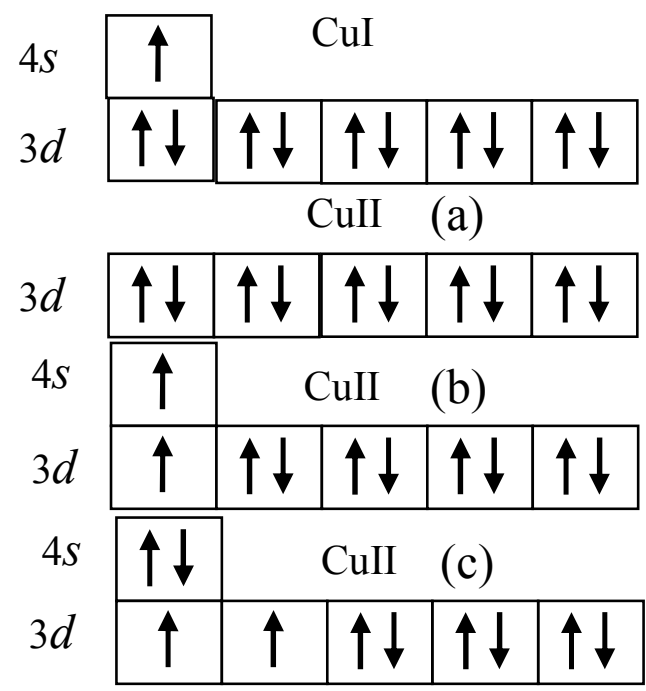

Figure 3 - Interaction of the additional electron with the integrated electric moment of a neutral atomic system

Фигура 3 - Взаимодействие дополнительного электрона со встроенным дипольным электрическим моментом нейтральной атомной системой

Slika 3 - Interakcija dodatnog elektrona sa ugrađenim dipolnim električnim momentom neutralnog atomskog sistema

The arrangement of electron spins for a neutral copper atom is shown in Fig. 2. In the process of copper atom ionization, it is possible to remove an electron from the $4 s$ or $3 d$ state. If an electron is removed from the $4 s$ state and a rearrangement of other electron cores in the $d$ state does not occur, then the electrons in the $d$-state form a closed core and that is the reason why their internal interaction does not lead to additional deformation of electron states and, consequently, internal integrated electric moments do not occur. In such a condition, the integrated electric dipole moment of a single ion of an atom equals zero. If a significant deformation of the electron cores occurs in the $3 d$ states and an ion of the copper atom tends to form a state characteristic for a nickel atom, then the conditions of electron spins shown in Figs. $2 b$ and $c$ are possible. The calculated values of the integrated electric dipole moment in the states of Fig. $2 b$ and Fig. $2 c$ are given in Table 1. Most probable is the occurrence of the state shown in Fig. 2 a.

When an unbounded electron is caught by a neutral atom, there is no interaction with the positive atom nucleus as the atom nucleus is completely shielded by the electrons around the atom. Nevertheless, the electron caught by the atom polarizes the atomic system by its field and then an interaction occurs not with the effective nucleus charge but with the displaced cloud of all electrons of the neutral atom occurring as a result of polarization. 
When there is an integrated electric moment, the outer unbounded electron interacts with the electrical dipole inside the atom (Fig. 3). In such a case, the atom can attach the electron and then can be transformed into a negative ion. The effect of the electrical field of this electron causes a displacement of the electron cloud of the neutral atom relating to its center of all energy states. If an external field is formed by the additional electron, the condition of forces equity for the valence electron of the atom in the $k$-state is as follows:

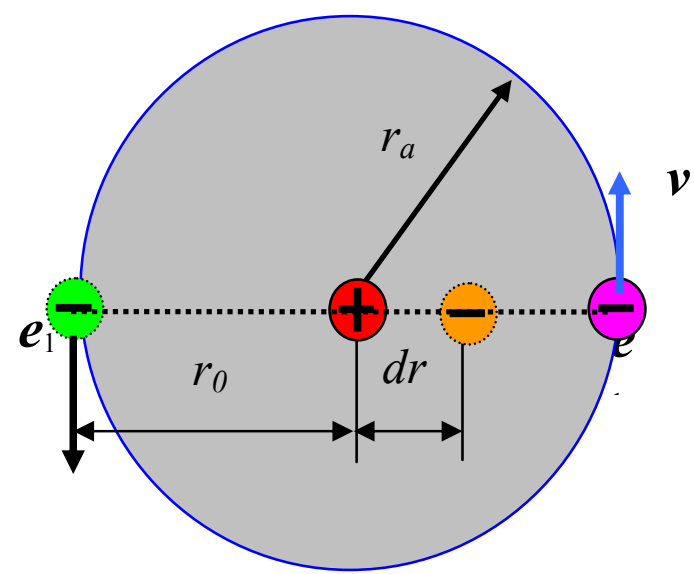

Figure 3 - Interaction of the additional electron with the integrated electric moment of a neutral atomic system

Фигура 3 - Взаимодействие дополнительного электрона со встроенным дипольным электрическим моментом нейтральной атомной системой

Slika 3 - Interakcija dodatnog elektrona sa ugrađenim dipolnim električnim momentom neutralnog atomskog sistema

$$
\frac{e^{2}}{4 \pi \varepsilon_{0} r_{0}^{2}}=\frac{Z_{k}^{*} e^{2}}{4 \pi \varepsilon_{0} r_{k}^{2}}-\frac{Z_{k}^{*} e^{2}}{4 \pi \varepsilon_{0}\left(r_{k}+\Delta r_{k}\right)^{2}}
$$

where $r_{k}$ - the rotation radius of the electron of the atom in the $k$-state, $Z_{k}^{*}$ - the effective atom nucleus charge in the $k$-state for the electron under consideration, $e-$ the charge, $\varepsilon_{0}$ - the dielectric permittivity constant and $r_{0}$ - the radius of the negative ion electron moving away from the atom center.

Hence, the displacement of the outer electron cloud of the $k$ energy state relating to the atom center is

$$
\Delta r_{k} \approx \frac{r_{k}^{3}}{2 Z_{k}^{*} r_{0}^{2}}
$$


The energy of the interaction of the outer electron with the integrated electric dipole of the atom taking into account the energy input for polarization is the electron affinity and it is as follows:

$$
E A \cong-\frac{2 e p_{e}}{4 \pi \varepsilon_{0} r_{0}^{2}}+\sum_{k} \frac{Z_{k}^{*} e^{2}}{4 \pi \varepsilon_{0}}\left[\frac{1}{r_{0}}-\frac{1}{r_{0}+\Delta r_{k}}\right]
$$

where $p_{e}-$ is the integrated electric dipole moment of the neutral atom. It is obvious that the interaction potential (3) will bear the minimum; otherwise, the system will not be stable. That is the reason why the electron affinity and the negative ion radius are determined by the minimum value of the interaction potential (3). The results of the interaction potential calculation for the atoms of carbon, oxygen and copper are given in Fig. $4 a$, while for titanium they are shown in Fig. $4 \mathrm{~b}$.

The energy of electron affinity can be measured with high accuracy, i.e. within the limits of $3 \%$. That is why, when using the values of atom affinity to an electron, one can obtain real values of the integrated electric dipole moments of complex atomic systems and, at the same time, the negative ion radius.

The electron affinity for the carbon atom at the atom radius $r_{a}=1.091$ $\AA$, the valence ion electron moving away from the atom center $r_{0}=1.095 \AA$ and $p_{e}=3.935 \cdot 10^{-30} \mathrm{Cm}$, calculated by equation (3) equals the experimental value $-1.263 \mathrm{eV}$. The radius of the carbon atom is slightly bigger than the value obtained by the quantum-mechanical method: $0.905 \AA$ (Brattsev, 1966 ) and 0.922 (Radtsig, Smirnov, 1980). When the atom radius equals $0.905 \AA$, the experimental value of the electron affinity has the effect when the electron moves away from the atom center in the negative ion $1.02 \AA$ and in the integrated electric dipole moment $p_{e}=3.089 \cdot 10^{-30} \mathrm{Cm}$. The interaction potential for such a case is given in Fig. $4 a$.
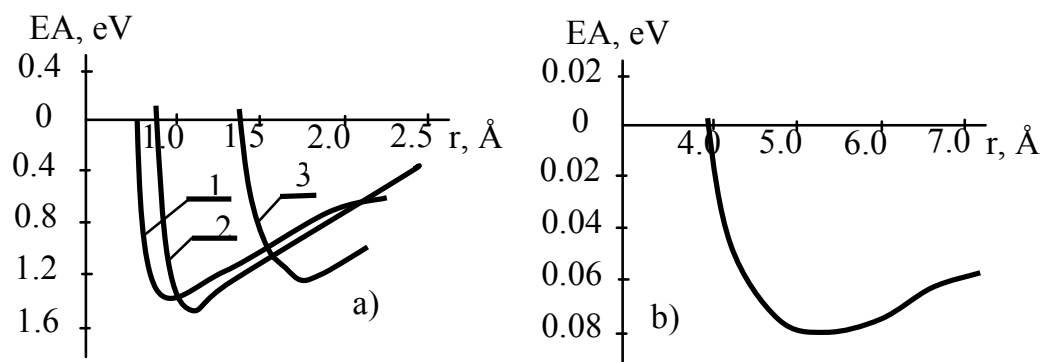

Figure 4 - Potential of interaction of the valence electron in the negative ion for: a) atom of carbon 1, atom of oxygen 2 and atom of copper 3 ; b) atom of titanium

Фигура 4 - Потенциал взаимодействия валентного электрона в отрицательном ионе а) для атома углерода 1, для атома кислорода 2 и для атома меди 3; б) для атома титана

Slika 4 - Potencijal interakcije valentnog elektrona u negativnom jonu a) za atome ugljenika 1, za atome kiseonika 2 i za atome bakra 3 ; b) za atome titanijuma 
For the atom of oxygen with the value of the integrated electric dipole moment $p_{\mathrm{e}, \mathrm{O}}=2.891 \cdot 10^{-30} \mathrm{Cm}$, the atom radius $=0.7073 \AA$ and the negative ion radius $r_{0}=1.04 \AA$, the affinity energy equals $-1.4611 \mathrm{eV}$, which corresponds to the measured experimental value. The radius of the oxygen atom in the reference book (Radtsig, Smirnov, 1980) equals $0.655 \AA$, in the reference book (Brattsev, 1966) $0.672 \AA$, and in the reference book (Physical values: Reference Book, 1991) $0.74 \AA$. For the radius $r_{a}=0.672 \AA$, the experimental value of the electron affinity has an effect at $r_{0}=1.01 \AA$ and the electric dipole moment $p_{e}=2.755 \cdot 10^{-30}$ $\mathrm{Cm}$. The interaction potential of the valence electron of the negative ion of oxygen is shown in Fig. $4 a$.

The calculated value of the electric dipole moment for the copper atom is $p_{e}=8.83 \cdot 10^{-30} \mathrm{Cm}$. When the atom radius equals $1.551 \AA$, the minimum of the potential curve corresponds to the experimental affinity value $1.23 \mathrm{eV}$ if the electron moves away from the atom center $-2.01 \AA$. When the copper atom radius equals $1.762 \AA$ (Radtsig, Smirnov, 1980), the experimental electron affinity value has an effect when the electron moves away from the atom center, $2.017 \AA$ with the integrated electric dipole moment $p_{e}=10.132 \cdot 10^{-30} \mathrm{Cm}$.

For titanium $p_{e}=4.08 \cdot 10^{-30} \mathrm{eV}$ and $r_{a}=1.811 \AA$ on the basis of equation (3), we obtain $E A=0.079 \mathrm{eV}$ at $r_{0}=5.37 \AA$. Taking into consideration the fact that the calculation of the integrated dipole moment is not accurate enough, it is known that when measuring the value of the dipole moment one obtains the experimental value of electron affinity equal to the experimental value, at $r_{a}=1.992 \AA$ (Radtsig, Smirnov, 1980), $r_{0}=5.55 \AA$ and $p_{e}=4.702 \cdot 10^{-30} \mathrm{Cm}$. The interaction potential for the negative ion of titanium is given in Fig. $4 b$.

Therefore, the electron affinity energy for atoms is determined by the interaction of the outer electron with the integrated electrical moment of a complex atomic system as well as by the columbic interaction of the valence electrons of negative ions and electrons of the neutral atom of all energy states. Integrated electric dipole moments for one force center are calculated by the quantum-mechanical method using actual values of the electrons radiuses of the atomic system in different energy states, and then affinity energy is determined using classic electrodynamics. This is sufficient for a practical use of the obtained electron affinity values. 


\section{Electron Affinity of Diatomic Molecules}

Electric dipole moments in diatomic molecules are oriented opposite to each other, as shown in Fig. 5. Bound energy in diatomic molecules is determined by the following interaction types: covalent, ionic, induced, electron-dipole and dipole-dipole (Grethcikhin, 2008).

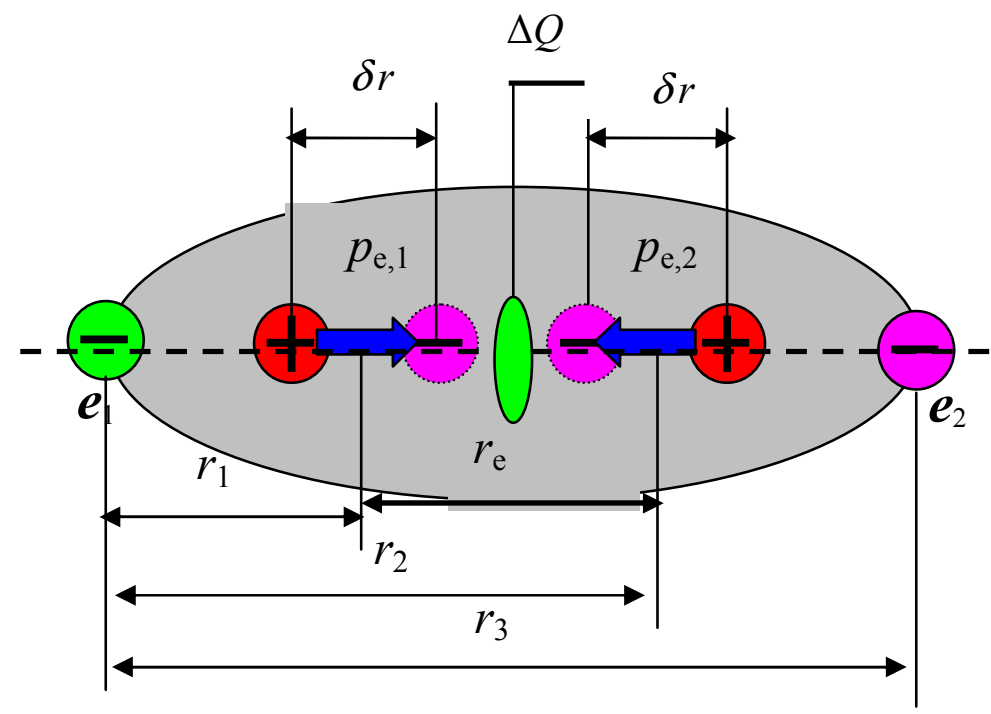

Figure $5-$ General diagram of the valence electron interaction with the diatomic molecule in the negative ion

Фигура 5 - Общая схема взаимодействия валентного электрона с двухатомной молекулой в отрицательном ионе

Slika 5 - Opšta šema interakcije valentnog elektrona sa dvoatomskim molekulama u negativnom jonu

Particular values of all bound types for the molecules of carbon, oxygen, copper and titanium are given in Table 2. The internuclear distance was considered as a variational parameter and was determined based on a condition when the dissociation energy and the ionization energy of the diatomic molecule correspond to the test data. The internuclear distances obtained in such a way exceed the values obtained on the basis of the vibration spectrums of diatomic molecules relating to the common center of gravity ${ }^{*}$.

\footnotetext{
*) The distance between atom nucleuses is determined by the interaction potential value and the distance between the electron clouds in the molecule - by the position of the interaction potential minimum.
} 
Table 2 - Value of the atoms bound energies in diatomic molecules and the ionization potential of diatomic molecules

Таблица 2 - Величина энергий связи атомов в двухатомных молекулах и потенциал ионизации двухатомных молекул

Tabela 2 - Vrednost energije veza atoma u dvoatomskim molekulima I potencijal jonizacije dvojatomskih molekula

\begin{tabular}{|c|c|c|c|c|c|c|c|c|c|c|}
\hline \multirow{2}{*}{$\begin{array}{l}\text { Mole } \\
\text { cule }\end{array}$} & \multicolumn{6}{|c|}{ Values of the various bound energies, eV } & \multirow[t]{2}{*}{$r_{\mathrm{e}}, \AA$} & \multirow[t]{2}{*}{$\Delta Q / e$} & \multirow{2}{*}{$\begin{array}{l}\theta_{\mathrm{i}} \\
\mathrm{eV}\end{array}$} & \multirow{2}{*}{$\begin{array}{c}r_{\mathrm{e} \text { eff, }} \\
\AA\end{array}$} \\
\hline & $E_{\text {cov }}$ & $E_{\text {ion }}$ & $\begin{array}{c}E_{\text {induc }} \\
\text { ed }\end{array}$ & $E_{e-d}$ & $E_{d-d}$ & $\begin{array}{c}E_{\text {resu }} \\
\text { It }\end{array}$ & & & & \\
\hline $\mathrm{O}_{2}$ & -4.45 & $\begin{array}{c}- \\
0.744\end{array}$ & $\begin{array}{c}- \\
0.194\end{array}$ & $\begin{array}{c}0.06 \\
0\end{array}$ & $\begin{array}{c}0.20 \\
8\end{array}$ & $\begin{array}{c}- \\
5.12\end{array}$ & $\begin{array}{c}1.60 \\
0\end{array}$ & $3.86 \cdot 10$ & $\begin{array}{l}12.0 \\
8\end{array}$ & $\begin{array}{l}1.51 \\
6\end{array}$ \\
\hline $\mathrm{C}_{2}$ & -5.44 & -0.86 & $0 . \overline{026}$ & $\begin{array}{c}0.01 \\
2\end{array}$ & $\begin{array}{c}0.11 \\
3\end{array}$ & $\begin{array}{c}- \\
6.20\end{array}$ & $\begin{array}{c}1.57 \\
0\end{array}$ & $1.0 \cdot 10^{-3}$ & 11.9 & $\begin{array}{l}1.49 \\
7\end{array}$ \\
\hline $\mathrm{Ti}_{2}$ & $0 . \overline{918}$ & $\begin{array}{c}- \\
0.069\end{array}$ & $\begin{array}{c}- \\
1.151\end{array}$ & $\begin{array}{c}0.55 \\
5\end{array}$ & $\begin{array}{c}0.38 \\
3\end{array}$ & $\begin{array}{c}- \\
1.20\end{array}$ & $\begin{array}{c}3.27 \\
6\end{array}$ & $3.8 \cdot 10^{-2}$ & 6.30 & $\begin{array}{l}3.61 \\
0\end{array}$ \\
\hline $\mathrm{Cu}_{2}$ & $\begin{array}{c}- \\
1.236\end{array}$ & $\begin{array}{c}- \\
0.083\end{array}$ & $\begin{array}{c}-\overline{-} \\
1.787\end{array}$ & $\begin{array}{c}0.67 \\
4\end{array}$ & $\begin{array}{c}0.38 \\
1\end{array}$ & $2 . \overline{0}$ & $\begin{array}{c}2.96 \\
1\end{array}$ & $4.3 \cdot 10^{-2}$ & 7.40 & $\begin{array}{l}3.60 \\
6\end{array}$ \\
\hline
\end{tabular}

It follows from the composition of diatomic molecules (Fig. 5) that they can attach two electrons and become a double negative ion. The affinity energy for a single negative ion equals:

$$
E A_{c p .} \cong-\frac{2 e p_{e, 1}}{4 \pi \varepsilon_{0} r_{1}^{2}}+\frac{2 e p_{e, 2}}{4 \pi \varepsilon_{0} r_{2}^{2}}+\frac{e \Delta Q}{4 \pi \varepsilon_{0} r_{m}}+\sum_{k} \frac{Z_{k}^{*} e^{2}}{4 \pi \varepsilon_{0}}\left[\frac{1}{r_{1}+r_{n}}-\frac{1}{r_{1}+r_{n}+\Delta r_{k}}\right]
$$

where $\Delta r_{k}=\frac{r_{e f f}^{3}}{2 Z_{k}^{*} r_{1}^{2}}$ and it determines the displacement of the valence electron cloud in the molecule; $Z_{k}^{*}$ - the effective molecule charge in the $k$ state; $r_{\text {eff }}$ - the effective molecule radius; $r_{1}$ - the distance to the center of the nearest atom determined by the position of the interaction potential minimum; $r_{m}$ - the distance to the molecule center, $r_{n}$ - the additional distance to the following atom, equal to $r_{e} ; p_{\mathrm{e}, 1}$ and $p_{\mathrm{e}, 2}-$ the corresponding integrated electric dipole moments of ions of the interacting atoms; and $\Delta Q$ - the induced charge occurring as a result of the valence electrons interchange in covalent atoms bound in the diatomic molecule.

The sum of potential (4) considers the energy input for polarization of the valence electron cloud of the diatomic molecule and for the polarization of the electron cloud of the positive core atoms. The electron cloud of the positive core atoms is shielded by the common electron cloud of the molecule. That is why, when an electron penetrates to the distance shorter than a single ionization molecule radius, the energy 
input for the polarization of the molecule core ions is considered. When the core polarization is taken into account, then the energies of the electron-dipole interaction bounds are not sufficient to penetrate deeper than the radius of the single ionization molecule ion.

In particular, the theoretical calculation of the electron affinity value as per (4) for the carbon molecule at the effective radius of interacting atoms of $0.905 \AA$ (Radtsig, Smirnov, 1980) and at the electric dipole moment of a single atom ion of the molecule positive core $p_{e, i}=1.976 \cdot 10^{-30} \mathrm{Cm}$ amounts to the experimental value of $-3.39 \mathrm{eV}$ (Physical Values: Reference Book, 1991) at the distance of moving away from the nearest atom $0.7643 \AA$, at which the electron approaches the atom center in the diatomic molecule under the effect of electron-dipole interaction, and the distance to the atom center amounts to $1.4975 \AA$, i.e. it is equal to the average effective radius of the molecule.

As for the oxygen molecule, the electron affinity amounts to $0.44 \mathrm{eV}$ (Physical Values: Reference Book, 1991).

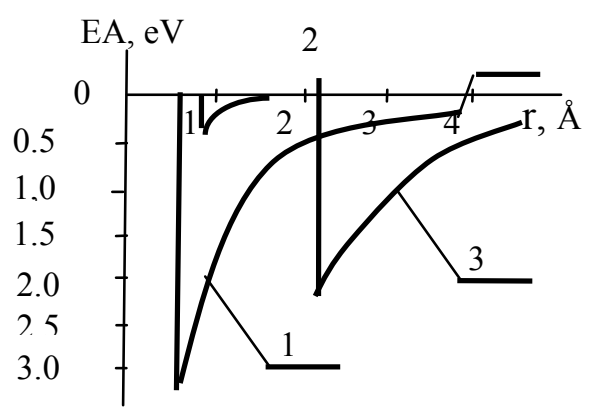

Figure 6 - Potential of the electron and molecule interaction: 1 - carbon, 2 - oxygen and 3 - titanium

Фигура 6 - Потенциал взаимодействия электрона с молекулой: 1 углерода; 2 - кислорода и 3 - титана

Slika 6 - Potencijal interakcije elektrona sa molekulom: 1. ugljenika; 2. kiseonika i 3. titanijuma

The electric dipole moment for the oxygen atom ion equals $2.755 \cdot 10^{-}$ ${ }^{30} \mathrm{Cm}$ (Grethcikhin, Shmermbekk, 2010). When the effective radius of the oxygen molecule amounts to $1.615 \AA$ and the distance of the electron moving away from the nearest atom is $0.964 \AA$, a complete overlapping of the theoretically calculated electron affinity with the experimentally measured value is observed.

In the diatomic titanium molecule, the effective radius is $r_{\text {eff }}=3.283 \AA$ and the positive ion of the atom upon the electron absence in the $3 d$-state has the integrated electric dipole moment $p_{e}=2.02 \cdot 10^{-30} \mathrm{Cm}$ (Table 1). The distance between the atoms in the molecule is $3.4635 \AA$, the effective radius of the diatomic titanium molecule is $3.283 \AA$, and the induced relative charge 
is $\Delta Q / e=0.0232$. In such conditions, the interaction of the electron with the molecule has positive energy and that is why it cannot be captured by the titanium molecule, i.e. the diatomic titanium molecule will not have electron affinity. If the electron detachment in the process of the titanium atom ionization occurs not from the state $3 d$, but from the state $4 s$, the dipole electric moment of the titanium atom ion will amount to $p_{e}=10.946 \cdot 10^{-30}$ $\mathrm{Cm}$, and the affinity energy will equal $E A=2.115 \mathrm{eV}$.

In the diatomic copper molecule, the positive ion of the molecule core does not have any electric dipole moment. Therefore, the electron affinity of the diatomic copper molecule equals zero.

The potential of the interaction of the electron with the neutral diatomic molecules of carbon, oxygen and titanium is given in Fig. 6 .

Through the example of the diatomic molecules of carbon, oxygen and titanium, it is demonstrated that the electron affinity in diatomic molecules is mainly determined by the interaction of the outer valence electron of the negative ion with the integrated electric dipole moments of complex atoms, with induced negative charge between interacting atoms and with the electron cloud of the neutral atom and its core.

\section{Electron Affinity of Triatomic Molecules}

A triatomic molecule is formed as a result of an atom interaction with a diatomic molecule. During this process, the common electron shell forms all the three valence electrons of complex atoms. That is the reason why the positive core of the triatomic molecule contains single positive ions of the initial atoms. The integrated electric dipole moments of the single ions are arranged so as to maximally increase the energy of the atom bound with the diatomic molecule. The arrangement of the atom relating to the diatomic molecule in the triatomic molecule is given in Fig. 7.

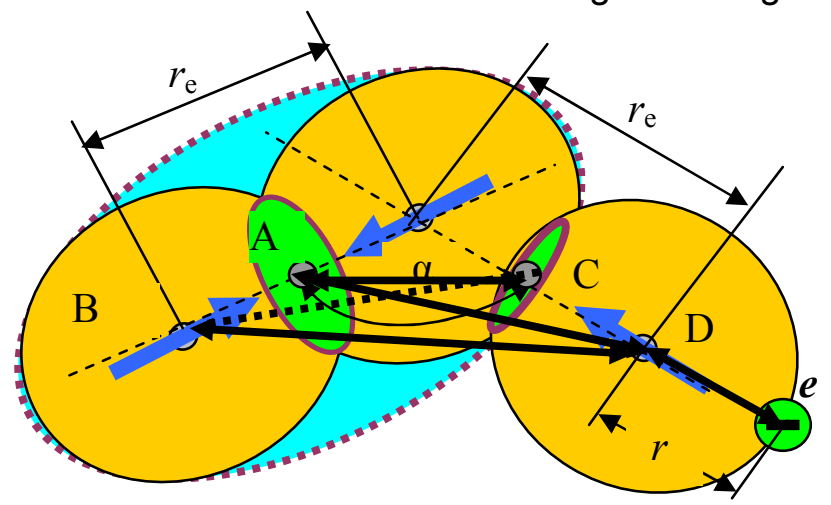

Figure 7 - General diagram of the negative ion of the unbounded triatomic molecule Фигура 7 - Общая схема отрицательного иона свободной трехатомной молекулы Slika 7 - Opšta šema negativnog jona slobodnog troatomskog molekula 
At the same time, the distance between the atoms is a few times bigger than the equilibrium distance between the atoms in the diatomic molecule due to the attraction of the nearest atom and the repulsion of the distant atom in the diatomic molecule. The nearest atom in the diatomic molecule is considered as the central one.

Moving away of the atoms from the central atom is nearly the same and is indicated in Fig. 7 by $r_{\mathrm{e}}$. Other distances are connected with the distance $r_{\mathrm{e}}$ in the following way: the distances $B D=r_{1}=2 r_{e} \sin (\alpha / 2)$;

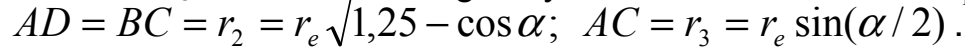

The calculation of dissociation energies in consideration of the data from Table 2 and the input data for the atoms given in (Physical Values: Reference Book, 1991) is accomplished by the methods described in (Grethcikhin, 2008) and demonstrated in Table 3.

Table 3 - Values energy of bounds of the various interaction types between the atom and the diatomic molecule

Таблица 3 - Значения: энергий связи разных типов взаимодействий между атомом и двухатомной молекулой

Tabela 3 - Vrednost: energije veza različitog tipa interakcije među atomom i dvoatomskim molekulom

\begin{tabular}{|c|c|c|c|c|}
\hline \multirow{2}{*}{ Parameters } & \multicolumn{4}{|c|}{ Chemical reactions } \\
\cline { 2 - 5 } & $\mathbf{C}+\mathbf{C}_{\mathbf{2}}$ & $\mathbf{O}+\mathbf{O}_{\mathbf{2}}$ & $\mathbf{T i}+\mathbf{T i}_{\mathbf{2}}$ & $\mathbf{C u}+\mathbf{C u}_{\mathbf{2}}$ \\
\hline$r_{e}, \AA$ & 1.570 & 1.552 & 3.276 & 2.961 \\
\hline$E_{\text {cov }}, \mathrm{eV}$ & -2.668 & -0.856 & -.918 & 1.553 \\
\hline$E_{\text {ion., }} \mathrm{eV}$ & -0.862 & -0.129 & -0.066 & -0.080 \\
\hline$E_{\text {induced., }} \mathrm{eV}$ & -0.281 & -0.176 & -0.583 & -0.832 \\
\hline$E_{\mathrm{e}-\mathrm{d}, \mathrm{eV}}$ & -0.102 & -0.066 & 0.488 & 0.544 \\
\hline$E_{d-d .}, \mathrm{eV}$ & -0.080 & -0.055 & 0.280 & 0.279 \\
\hline$E_{\text {result, }} \mathrm{eV}$ & -4.00 & -1.04 & -0.98 & -1.64 \\
\hline$\Delta q / e$ & 0.0101 & 0.00986 & 0.0387 & 0.0411 \\
\hline$P_{e}, \mathrm{C} \cdot \mathrm{m} 10^{30}$ & 1.976 & 2.755 & 10.95 & 9.39 \\
\hline$\theta_{i,} \mathrm{eV}$ & 12.69 & 12.52 & 8.76 & 10.51 \\
\hline$r_{\text {eff. }} \AA$ & 2.086 & 2.169 & 4.025 & 3.885 \\
\hline
\end{tabular}

The triatomic molecule catches the electron to its outer orbit. The energy of the triatomic molecule affinity is determined by the interaction with the integrated dipole moments of all the three ions of the positive core and by its polarization. The distance of the caught electron from the molecule center does not exceed its effective radius. The electron affinity energy with the positive core of the triatomic molecule is mainly 
determined by the interaction of the valence the electron has with the integrated electric dipole moment of the nearest ion. The distance at which the electron approaches the nearest ion of the atomic core does not exceed the radius of the triple ion of the molecule. According to Fig. 7 , the resultant bound energy of the valence electron of the triatomic molecule negative ion equals

$$
E A_{1 .}=-E_{1}+E_{2}+E_{3}+E_{4}-E_{5}+E_{6} \text {, }
$$

where $E_{1}=\frac{2 e p_{э}}{4 \pi \varepsilon_{0} r^{2}} ; E_{2}=\frac{e \Delta Q}{4 \pi \varepsilon_{0}\left(r+r_{e} / 2\right)} ; E_{3}=\frac{e \Delta q}{4 \pi \varepsilon_{0}\left(r+r_{2}\right)}$;

$$
E_{4}=\frac{2 \cos (\pi-\alpha) e p_{\ni}}{4 \pi \varepsilon_{0}\left(r+r_{e}\right)^{2}} ; E_{5}=\frac{2 e p_{\ni} \cos \left(\frac{\pi-\alpha}{2}\right)}{4 \pi \varepsilon_{0}\left(r+r_{1}\right)^{2}} ;
$$

$E_{6}=\sum_{k} \frac{Z_{k}^{*} e^{2}}{4 \pi \varepsilon_{0}}\left(\frac{1}{r+r_{2} / 2}-\frac{1}{r+r_{2} / 2+\Delta r_{k}}\right)$ и $\Delta r_{k}=\frac{r_{\ni \phi \phi}^{3}}{2 Z_{k}^{*}\left(r+r_{2} / 2\right)^{2}}$.

When the triatomic molecule becomes the double-negative ion, the bound energy of the second electron weakens and can be determined by the equation

$$
E A_{2}=E A_{1}+\frac{e^{2}}{4 \pi \varepsilon_{0} 3 r_{a}}
$$

Particular calculations by equations (5) in consideration of the input data from Table 2 and Table 3 are given in Table 4 . The appearance of the potential of the electron interaction with various triatomic molecules is given in Fig. 8.

Table 4 - Input data and the interaction energy of the electron affinity of various triatomic molecules

Таблица 4 - Исходные данные и энергия взаимодействия сродства к электрону разных трехатомных молекул

Tabela 4 - Inicijalni podaci i energija interakcije

\begin{tabular}{|l|l|l|l|}
\hline \multirow{2}{*}{ Parameters } & \multicolumn{2}{|c|}{ Negative ions } & $T_{3}^{-}$ \\
\cline { 2 - 4 } & \multicolumn{1}{|c|}{$C_{3}^{-}$} & \multicolumn{2}{c|}{$O_{3}^{-}$} \\
\hline$r_{\mathrm{e}}, \AA$ & 1.523 & 1.552 & 3.276 \\
\hline$r_{\mathrm{a}}, \AA$ & 0.905 & 0.672 & 3.610 \\
\hline$r_{\mathrm{b}}, \AA$ & 1.497 & 1.516 & 1.992 \\
\hline$r_{\mathrm{eff}}, \AA$ & 2.086 & 2.169 & 4.025 \\
\hline$r_{0}, \AA$ & 0.838 & 0.857 & 1.992 \\
\hline$E A, \mathrm{eV}$ & 2.500 & 2.100 & 3.383 \\
\hline
\end{tabular}




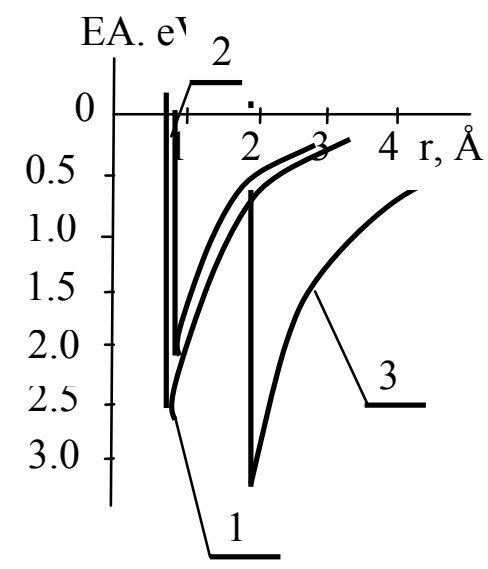

Figure 8 - Potential of the electron interaction with the triatomic molecule: 1 carbon, 2 oxygenand 3 titanium

Фигура 8 - Потенциал взаимодействия электрона с трехатомной молекулой: 1 - углерода; 2 - кислорода и 3 - титана

Slika 8 - Potencijal interakcije elektrona sa troatomskim molekulom:

1. ugljenika, 2. kiseonika i 3. titanijuma

It appears that the greatest value of the electron affinity is found in the triatomic molecules in the unbounded state.

\section{Conclusions}

As a result of the studies performed, the following was established:

1. In the process of the negative ion formation, one is to consider the outer electron interaction with the integrated electric dipole moments of separate atoms, the induced negative cloud in the contact area as well as with the valence electron of the initial neutral particle. For such interactions, it is not correct to perform quantum-mechanical calculations with a use of the Schrödinger equation.

2 . In the process of the determination of the electron affinity to the atom, one is to consider the electron interactions with the integrated electric dipole moment of the neutral atom and the repulsion force of the neutral atom valence electrons and negative ions in accordance with Coulomb's law.

3. The electron affinity to the diatomic molecule is determined by the electron interaction with two integrated electric dipole moments of the atomic ion, the induced negative cloud at the border of atoms segregation in the molecule as well as by the columbic interaction of the valence electrons of the negative ion and the neutral molecule. 
4. In the process of the electron capturing by the triatomic molecule, affinity energy is determined by the electron interaction with the integrated electric dipole moments of all the three ions forming the positive core of the molecule as well as by the columbic interaction of the outer electron with the electron cloud of the triatomic molecule and the induced charges.

\section{Лumepamypa / Literature}

Бабичев, А.П., Бабушкина, Н.А., Братковский, А.М., \& и др, 1991. Физические величины: Справочник. Под ред. Григорьева, И.С. Мейлихова, Е.3., Москва: Энергоатомиздат., стр.1232. (Babichev, A.P., Babushkina, N.A., Bratkovskiy, A.M. et al, 1991. Physical quantities: Reference book. Edited by Grigoriev, I.S., Meilikhov, E.Z., Moscow, Energoatomizdat, p.1232).

Братцев, В.Ф., 1966. Таблицы атомных волновых функций. Изд. «Наука», стр.192. (Brattsev, V. F., 1966. Tables of atomic wave functions, p.192) .

Гречихин, Л.И. 2003. Взаимодействие твердого тела с окружающей средой в околоземном космическом пространстве (Эффрект Гречихина)/ Первый Белорусский космический конгресс, Минск: ИПИ НАНБ., стр.31. (Gretchikhin, L. I. 2003. Interaction of a solid with surroundings in circumterrestrial outer space (Gretchikhin effect). .In: The First Belarusian Space Congress, Minsk, October 28-30, p.31).

Гречихин, Л.И., Тюнина, Е.С. 1967. Исследования электродных фракелов дугового разряда. Журнал «Физика и химия обработки материалов», 11(3), стр.2728. (Gretchikhin, L.I., Tyunina, E.S. 1967. Studies on electrode flares of arc discharge. Physics and chemistry of materials processing, 11(3). pp.27-28).

Гречихин, Л.И., Минько, Л.Я. 1967. Об аналогии физических процессов, протекающих в импульсном разряде и при воздействии концентрированного лазерного излучения, /ЖТФ, 37. (Gretchikhin, L.I., Minko, L.Y. 1967. About the analogy of physical processes taking place in impulse discharge and when exposed to concentrated laser radiation, Technical Physics, 37).

Гречихин, Л. 2008. Наночастицы и нанотехнологии, Право и экономика, стр.406. (Gretchikhin, L.I. 2008. Nanoparticles and nanotechnologies, Pravo i ekonomika, p.406).

Гречихин, Л.И., Шмермбекк, Ю. 2010. Наноуровень обоснования ОКГ конденсированных сред, Право и экономика, стр.75. (Gretchikhin, L.I., Shmermbekk, Y. 2010. The nanolevel of substantiation of the optical quantum generator of condensed matters. Pravo i ekonomika, p.75).

Johnson, C.J., Heppner, J.P. 1956. Daytime measurement of positive and negative ion composition to $131 \mathrm{~km}$ Rocket-borne/Дневное измерение состава положительных и отрицательных ионов бортовыми спектрометрами на расстоянии до 131 км. J. Geophys. Res., 61(3), p.575.

Massey, H. 1976. Negative ions/Oтрицательные ионы.Cambridge: Cambridge University Press., p.753.

Радциг, А.А., Смирнов, Б.М. 1980. Справочник по атомной и молекулярной фозике/Reference book on atomic and molecular physics.Москва: Атомиздат., стр.240. (Radtsig, A.A., Smirnov, B.M. 1980. Reference book on atomic and molecular physics. Moscow: Atomizdat, p.240). 
ОТРИЦАТЕЛЬНЫЕ ИОНЫ АТОМОВ, ДВУХАТОМНЫХ И ТРЕХАТОМНЫХ МОЛЕКУЛ

Леонид И. Гречихин ${ }^{\text {, }}$ Виктория М. Комаровскаяб

а Белорусская государственная академия связи, г. Минск,

Республика Беларусь,

${ }^{б}$ Белорусский национальный технический университет, г. Минск,

Республика Беларусь,

ОБЛАСТЬ: материалы, нанотехнология, структура и свойства

отрицательных ионов

ВИД СТАТЬИ: оригинальная научная статья

ЯЗЫК СТАТЬИ: английский

Краткое содержание:

Сродство к электрону не определяется путем решения уравнения Шредингера, а определяется большой совокупностью разных типов взаимодействий. В атомах основной вклад в сродство к электрону вносит связь между внешним электроном и встроенным дипольным электрическим моментом нейтрального атома. В двухатомных молекулах энергию сродства преимущественно определяет взаимодействие внешнего электрона со встроенным дипольным электрическим моментом ближайшего иона. В трехатомной молекуле внешний электрон взаимодействует со всеми встроенными дипольными моментами положительного остова.

Ключевые слова: дипольный момент, отрицательный ион, атом, двухатомная молекула, трехатомная молекула.

\section{NEGATIVNI JONI ATOMA, DVOATOMSKIH I TROATOMSKIH MOLEKULA}

Leonid I. Grečihin ${ }^{a}$, Vktorija M. Komarovskaja ${ }^{\mathrm{b}}$

a Beloruska državna akademija saobraćaja i veza, Minsk, Republika Belorusija

${ }^{\mathrm{b}}$ Beloruski nacionalni tehnički univerzitet, Minsk, Republika Belorusija

OBLAST: materijali, nanotehnologije, struktura i karakteristike negativnih jona VRSTA ČLANKA: originalni naučni članak JEZIK ČLANKA: engleski

Sažetak:

Afinitet prema elektronu ne određuje se putem rešenja Šredingerove jednačine, nego uz pomoć velikih skupova različitih tipova kovalentnih veza. 
Najveći doprinos za afinitet prema elektronima imaju veze između spoljašnjih elektrona i ugrađenih dipolnih električnih momenata neutralnog atoma.

$U$ dvoatomskim molekulima energija afiniteta se primarno određuje interakcijom spoljašnjeg elektrona sa ugrađenim dipolnim električnim momentom najbližeg jona.

$U$ troatomskom molekulu spoljašnji elektron stupa u kovalentnu vezu sa svim ugrađenim dipolnim momentima valentnih ljuski atoma.

Ključne reči: dipolni momenat, negativni jon, atom, dvoatomski molekul, troatomski molekul.

Paper received on / Дата получения работы / Datum prijema članka: 07. 12. 2015.

Manuscript corrections submitted on / Дата получения исправленной версии работы / Datum dostavljanja ispravki rukopisa: 05. 01. 2016.

Paper accepted for publishing on / Дата окончательного согласования работы / Datum konačnog prihvatanja članka za objavljivanje: 07. 01. 2016.

(c) 2016 The Authors. Published by Vojnotehnički glasnik / Military Technical Courier (www.vtg.mod.gov.rs, втг.мо.упр.срб). This article is an open access article distributed under the terms and conditions of the Creative Commons Attribution license (http://creativecommons.org/licenses/by/3.0/rs/).

() 2016 Авторы. Опубликовано в "Военно-технический вестник / Vojnotehnički glasnik / Military Technical Courier" (www.vtg.mod.gov.rs, втг.мо.упр.срб). Данная статья в открытом доступе и распространяется в соответствии с лицензией "Creative Commons" (http://creativecommons.org/licenses/by/3.0/rs/).

(C) 2016 Autori. Objavio Vojnotehnički glasnik / Military Technical Courier (www.vtg.mod.gov.rs, втг.мо.упр.срб). Ovo je članak otvorenog pristupa i distribuira se u skladu sa Creative Commons licencom (http://creativecommons.org/licenses/by/3.0/rs/).

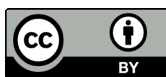

